\title{
固体表面の濡れ，粒子間毛管力, Pickering エマルション の流体シミュレーション \\ Computational Fluid Dynamics Study of Wetting, Capillary Forces, and Pickering Emulsions
}

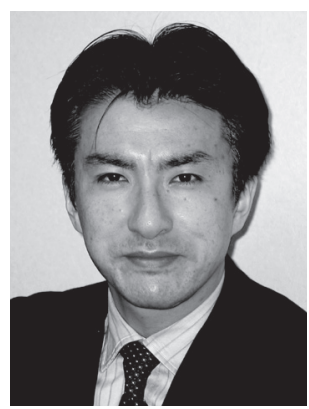

\author{
新戸 浩幸 \\ 京都大学大学院工学研究科化学工学専攻 \\ 干 615-8510 \\ 京都市西京区京都大学桂 \\ Hiroyuki SHINTO \\ Department of Chemical Engineering, Kyoto \\ University \\ Katsura Campus, Nishikyo-ku, Kyoto 615-8510, \\ Japan
}

論文要旨：本稿では, フェイズフィールドモデルに基づく数值流体力学法を概説し, 固体状物体が含まれ た二相流体で頻繁に見られる現象への適用例（ここでは, 固体表面上の濡れ, 粒子間毛管力, Pickering エ マルション）を紹介する。数種類の粒子間毛管力とその重要性についても，概説する。

\begin{abstract}
The present review gives a brief introduction to computational fluid dynamics (CFD) with a phase-field model for the simulation of wetting and capillary forces as well as the Pickering emulsions, which usually appear in a two-phase fluid system including solid bodies. Several types of capillary forces and their importance over other forces such as van der Waals force and electrostatic force are also explained.
\end{abstract}

Key words: computational fluid dynamics, phase-field model, wettability, capillary-bridge force, lateral capillary force, pickering emulsion

\section{1 はじめに}

砂城をつくろうとするとき, 砂を水で適度に湿らすの が良いことは, 砂場や砂浜での遊びを通して, 誰しもが 体験しているであろう。また，川面に浮かぶ泡やごみ， ラーメン汁の表面に浮かぶ胡麻などを注意深く観察する と, これらは自然に集まることに気付くであろう。結論 から先に言えば, 前者では毛管架橋力 (capillary-bridge force）が, 後者では横毛管力 (lateral capillary force) が, 自己集合の駆動力となっている。この二種類の毛管力 (capillary force) は, 自然界やわれわれの身の周りばか りでなく, 種々の産業プロセスでも, 頻繁に現れる力で ある。最近では, 材料プロセスにおける粒子集積化技術 の一手段として, 毛管力が注目され積極的に利用されて

連絡者：新戸 浩幸

E-mail : shinto@cheme.kyoto-u.ac.jp
いる ${ }^{1)}$ 。

本稿では，固体表面の濡れとその結果として二表面間 に発生する毛管力に焦点を絞る。毛管架橋力（第 2 節） と横毛管力（第 3 節）について概説した後, フェイズ フィールドモデルに基づく流体シミュレーション法（第 4 節）と著者らによるその適用例（第 5 節）を紹介する。

\section{2 毛管架橋力}

$2 \cdot 1$ 物体間の間隙での毛管相分離は引力をもたらす ${ }^{2-4)}$ 粉体の付着は, 大気中の湿度に非常に敏感である。こ れは，大気中の水分子が粒子間の接触部または間隙に液 体として毛管凝縮し, その結果生じる液架橋力が粒子ど うしを強く引きつけるからである（Fig. 1, Table 1 の 系 1）。毛管凝縮は「気相から液相へ」の相転移であるが, Table 1 に示すように, その反対の「液相から気相へ」 の相転移（系 2), 二成分液体における「液相から液相へ」 
(a)毛管架橋前

\section{$\mathrm{S}$}

\section{A}

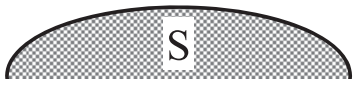

(b)毛管架橋後

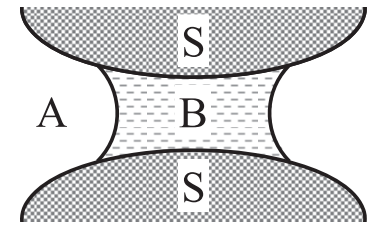

Fig. 1 二つの固体表面 S に挟まれたバルク相 A と誘起され た相 B：（a）毛管相分離前，（b）毛管相分離後 ${ }^{10)}$ 。

の相分離（系 3,4）も起こりうる。さらに, Table 1 の系 5〜7のように，上り複雑な分子からなる溶液も，相分 離しうることが報告されている。このような固体表面間 の間隙に打いて起こる相分離は，一般的に毛管相分離 (capillary phase separation) と呼ばれる。その結果と して生じる毛管架橋力は，常に引力である。

Table 1 を注意深くみると, 固体表面 $\mathrm{S}$, バルク相 $\mathrm{A}$, 誘起される相 B の組み合わせに，どの系にも同様な傾 向があることに気付くであろう。毛管相分離が生じる系 では, 固体表面 S は, バルク相 $\mathrm{A}$ とは低い親和性しか 示さないが，誘起される相 B とは高い親和性を示すの である。当然のことながら，系 1 に扔いて，固体表面を 親水性から疎水性に変化させると, 毛管凝縮は起こらな い。

\section{$2 \cdot 2$ 毛管架橋力の表現式 ${ }^{2-4)}$}

二球間（半径 $R_{1}, R_{2}$ ；表面間距離 $D$ ）に働く毛管架 橋力 $F(D)$ の表現式は, 二球間隙に毛管架橋した相 B のメニスカス形状を考虑し, 界面張力と毛管圧力からの 寄与の和として力を書き下せば, 次式のように得られる。

$$
F(D)=-4 \pi \gamma_{\mathrm{AB}} \cos \theta \cdot \frac{R_{1} R_{2}}{R_{1}+R_{2}}\left(1-\frac{D}{D_{\text {cap }}}\right)
$$

for $0 \leq D<D_{\text {cap }}$

ここで， $\gamma_{\mathrm{AB}}$ は異相 $\mathrm{A} / \mathrm{B}$ 間の界面エネルギーを， $\theta$ は $\mathrm{A}$ 相中の固体表面 Sに対して B 相が示す接触角を, $D_{\text {cap }}$

は毛管相分離が生じるときの表面間距離を，それぞれ表 す。B 相が固体表面 Sを濡らす状況を考えているので, $0 \leq \theta<90^{\circ}$ である。

\section{$2 \cdot 3$ 液架橋力は他の力と比較して強い}

気相中・液相中を問わず，通常，粒子間には毛管架橋 力の他に数種類の力が同時に働く。ここでは, 接触した 二粒子間 $(D=0)$ に働く力として液架橋力 $F_{\text {cap }}$, ファン デルワールスカ（van der Waals force） $F_{\text {vdW }}$, 静電気力 $F_{\mathrm{el}}$ を, 単一粒子に働く力として重力 $F_{\mathrm{g}}$ を取り上げ，こ れら力の大きさを比較してみる。Eq.（1）および文献 4） によれば, これらの力は次式のように与えられる。

$$
\begin{aligned}
& F_{\text {cap }}=-4 \pi \gamma_{\mathrm{AB}} \cos \theta \cdot \frac{R_{1} R_{2}}{R_{1}+R_{2}} \\
& F_{\text {vdW }}=-\frac{A_{\mathrm{H}}}{6 D_{0}^{2}} \frac{R_{1} R_{2}}{R_{1}+R_{2}} \\
& F_{\mathrm{el}}=\frac{4 \pi \sigma_{1} \sigma_{2}}{\varepsilon_{0}}\left(\frac{R_{1} R_{2}}{R_{1}+R_{2}}\right)^{2} \\
& F_{\mathrm{g}}=\frac{4 \pi}{3} R_{\mathrm{i}}^{3} \rho_{\mathrm{i}} g
\end{aligned}
$$

ここで， $A_{\mathrm{H}}$ はハマカー定数 (Hamaker constant) で物 質に固有な值であり， $D_{0}$ は接触時の粒子表面間距離 $\left(0.4 \mathrm{~nm}\right.$ とされる場合が多い)， $\sigma_{i}$ は粒子 $i(=1,2)$ の 表面電荷密度, $\rho_{i}$ は粒子 $i$ の質量密度をそれぞれ表す。 $\varepsilon_{0}$ は真空の誘電率 $\left(8.85 \times 10^{-12} \mathrm{~F} \mathrm{~m}^{-1}\right), g$ は重力加速 度 $\left(9.8 \mathrm{~m} \mathrm{~s}^{-2}\right)$ を表す。

Eqs.（2）－（5）を用いると, 粒子に働く重力と粒子間付 着力（液架橋力, ファンデルワールス力, 静電気力）に

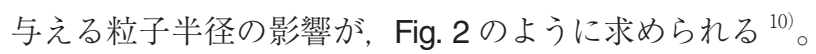
液架橋力 $F_{\text {cap }}$ とファンデルワールス力 $F_{\text {vdW }}$ は, 粒子半 径 $R$ に比例して増大する $\left(F_{\text {cap }}, F_{\mathrm{vdW}} \propto R\right)$ 。一方, 静 電気力 $F_{\mathrm{el}}$ は, 表面電荷密度 $\sigma\left(=26.5 \mu \mathrm{C} \mathrm{m}^{-2}\right.$ は気中で

\begin{tabular}{|c|c|c|c|c|c|}
\hline 系 & $\begin{array}{c}\mathrm{S} \\
\text { 固体表面※ }\end{array}$ & $\begin{array}{c}\mathrm{A} \\
\text { バルク相 } ※\end{array}$ & $\begin{array}{c}\text { B } \\
\text { 誘起される相※ }\end{array}$ & $\begin{array}{l}\text { バルク相 A と } \\
\text { 誘起相 B の差異 }\end{array}$ & 備考 \\
\hline 1 & 親水性 & 水蒸気（湿り空気） & 水 & 密度 & 毛管凝縮, 液架橋力 \\
\hline 2 & 疎水性 & 水 & 水蒸気 (空気) & 密度 & 毛管蒸発, 疎水性相互作用力 \\
\hline 3 & 親水性 & 微量の水分を含んた眯水性溶媒 & 水 & 微量成分の濃度 & 非水分散系 \\
\hline 4 & 疎水性 & 微量の疎水性溶質を含んだ水 & 疎水性溶媒 & 微量成分の濃度 & \\
\hline 5 & マイカ & スポンジ相 & ラメラ相 & 高次構造 & water-AOT- $\mathrm{NaNO}_{3}$ 混合系 5.6) \\
\hline 6 & マイカ & 高分子 $\alpha$ と $\beta$ の混合水溶液 & 高分子 $\beta$ の水溶液 & 高分子 $\beta$ の濃度 & water-dextran-PEO 混合系 ${ }^{7)}$ \\
\hline 7 & 垂直, 水平配向性 & サーモトロピック液晶の等方相 & ネマチック相 & 分子配向 & $8 \mathrm{CB}$ 液晶 ${ }^{8,9)}$ \\
\hline
\end{tabular}
の限界值 $\left.{ }^{4}\right)$ が同じであれば, 粒子半径の二乗に比例し $\left(F_{\mathrm{el}} \propto R^{2}\right)$, 重力 $F_{\mathrm{g}}$ は粒子半径の三乗に比例する $\left(F_{\mathrm{g}} \propto\right.$ $\left.R^{3}\right)$ 。Fig. 2 からわかるように, 粒径が $1 \mathrm{~mm}$ を越えな

Table 1 毛管相分離と毛管架橋力を生じる系 $(\text { Fig. } 1 \text { を参照 })^{10)}$ 。

※ Fig. 1 中の S, A, B と対応している。 


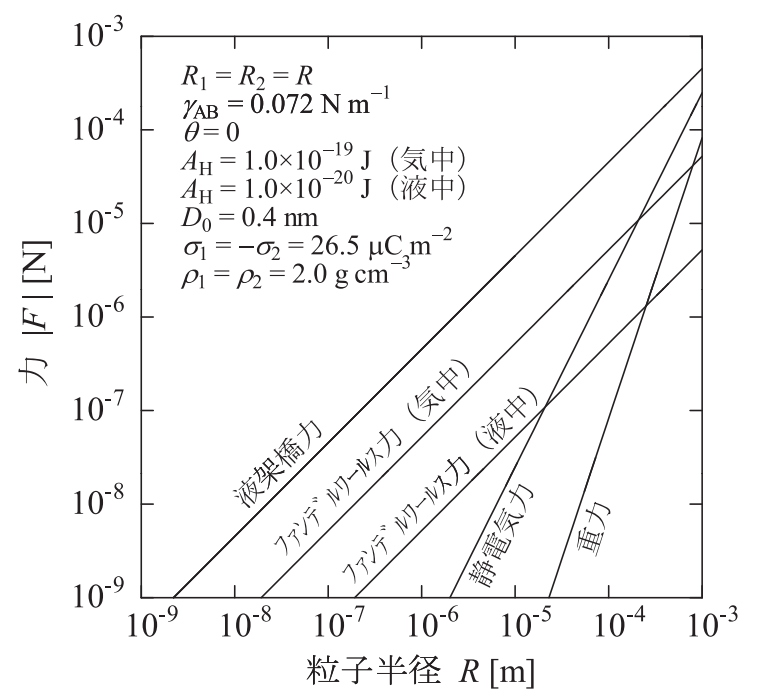

Fig. 2 粒子に働く重力と粒子間付着力（液架橋力, ファン デルワールス力, 静電気力）に与える粒子半径の影 響 ${ }^{10)}$ 。

ければ，液架橋力は他の力と比較べて非常に強く，その 強さの比は粒子が小さくなるほど顕著になる。

\section{3 横毛管力}

\section{3・1 粒子による液表面の変形は表面張力由来の横毛 管力をもたらす}

Fig. 3 （a）に示すように, 水に浮かぶ粒子を考えよう。 粒子は, その表面の物理化学的性質によって, 大きく分 けて親水性と疎水性の場合がある。この濡れ性（wettability）のため，粒子の周りの水の表面は平坦ではなく， 盛り上がったり窪んだりした曲面である。この曲面はメ ニスカスと呼ばれる。水表面のこのような変形は, 常に 自由エネルギー的に不利である。

いま，水表面に二つの粒子があるとしよう。この水表 面の変形の度合いは，二粒子間の相対距離によってずい ぶん変わる。この二つの粒子は, 互いに近づくか, 遠ざ

(a)

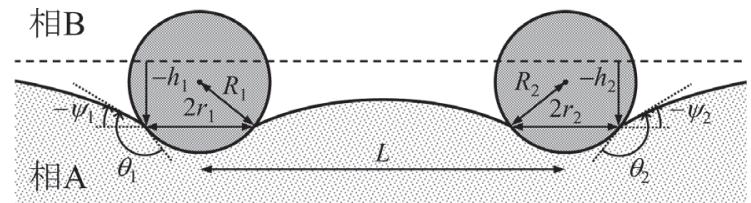

(b)

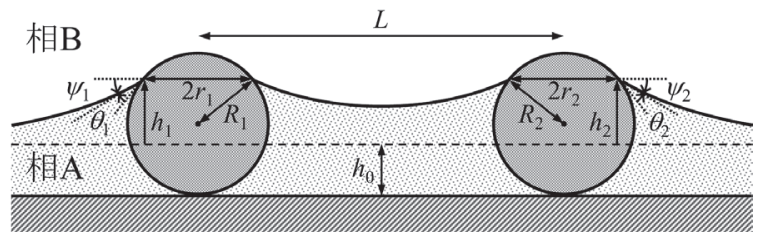

Fig. 3 （a）液表面に浮いている二粒子,

（b）基板上に乗り 液膜中に浸っている二粒子 ${ }^{10)}$ 。
かるように動くであろう。これは，水の表面変形を小さ くしてエネルギー的に不利な状態を避けようとした結果 である。このように，粒子が中途半端に水に浸っている と水面を変形させ，その変形が表面張力を通して粒子間 に働く力となる。この力が，横毛管力である。

\section{$3 \cdot 2$ 横毛管力の表現式 ${ }^{11-15)}$}

重力下において, 高密度な液体 $\mathrm{A}$ （質量密度 $\rho_{\mathrm{A}}$ ）と 低密度な流体 $\mathrm{B}$ （質量密度 $\rho_{\mathrm{B}}$ ) の二相界面（界面張力 $\left.\gamma_{\mathrm{AB}}\right)$ に, 粒子 $i\left(=1,2\right.$; 質量密度 $\rho_{i}$, 半径 $\left.R_{i}\right)$ が付着 した場合を考える。粒子中心間の水平距離を $L$ とすると, 二粒子間の毛管相互作用エネルギー $\Delta W$ と横毛管力 $F$ は, 次のように与えられる。

$$
\begin{aligned}
& \Delta W=-2 \pi \gamma_{\mathrm{AB}} Q_{1} Q_{2} K_{0}(q L) \text { for } r_{i} \ll L \\
& F=-\frac{\mathrm{d} \Delta W}{\mathrm{~d} L}=-2 \pi \gamma_{\mathrm{AB}} Q_{1} Q_{2} q K_{1}(q L) \text { for } r_{i} \ll L
\end{aligned}
$$

ここで, $K_{0}(x)$ と $K_{1}(x)$ はそれぞれ一次, 二次の第一 種変形ベッセル関数を表す。濡れ接触部位の半径 $r_{i}$, 毛 管電荷 (capillary charge) $Q_{i}$, 毛管長 (capillary length) の逆数 $q$ は, 次式のように与えられる。

$$
\begin{aligned}
& r_{i}=R_{i} \sin \left(\psi_{i}+\theta_{i}\right) \\
& Q_{i}=r_{i} \sin \psi_{i} \\
& q=\sqrt{\frac{\left(\rho_{\mathrm{A}}-\rho_{\mathrm{B}}\right) g}{\gamma_{\mathrm{AB}}}}
\end{aligned}
$$

ここで， $\psi_{i}$ は粒子 $i の$ 表面におけるメニスカスの傾き, $\theta_{i}$ は高密度液体 $\mathrm{A}$ に対する粒子 $i$ の接触角をそれぞれ 表す。毛管電荷 $Q_{i}$ は, 濡れの幾何学的性質 $\left(r_{i}, \psi_{i}\right)$ を 表し, クーロン相互作用における電荷と同じように，正 と負の符号をとれる。Eq. (9) から, 毛管電荷 $Q_{i}$ の符 号は，メニスカスの傾き $\psi_{i}$ の符号と一致する。Eq. (7) からわかるように，横毛管力は，毛管電荷 $Q_{1}$ と $Q_{2}$ が 同符号であれば引力となり, 異符号であれば斥力となる。

\section{$3 \cdot 3$ 二種類の横毛管力 : 浮体力と液浸力 ${ }^{11-15)}$}

横毛管力の大きさは, 粒子が液表面に浮いている場合 （Fig. 3（a））と粒子が基板上に乗り液膜中に浸ってい る場合（Fig. 3（b)）とでは, 著しく異なる。前者は浮 体力 (capillary flotation force), 後者は液浸力 (capillary immersion force）と呼ばれ，明確に区別されている。

浮体力と液浸力の粒子半径依存性について調べてみよ う。ここでは問題を単純化するため, 二粒子が同じ種類 の場合 $\left(R_{1}=R_{2}=R, \theta_{1}=\theta_{2}=\theta, \rho_{1}=\rho_{2}=\rho_{\mathrm{S}}, \quad r_{1}=r_{2}=r\right.$, $\left.\psi_{1}=\psi_{2}=\psi, Q_{1}=Q_{2}=Q, h_{1}=h_{2}=h\right)$ を考える。 $L=2 R($ 二 粒子は接触) $, \theta=30^{\circ}, \rho_{\mathrm{A}}=1.0 \mathrm{~g} \mathrm{~cm}^{-3}, \rho_{\mathrm{B}}=0, \gamma_{\mathrm{AB}}=0.072 \mathrm{~N}$ $\mathrm{m}^{-1}, \rho_{\mathrm{S}}=2.0 \mathrm{~g} \mathrm{~cm}^{-3}$ (浮体力の場合), $h_{0}=R$ (液浸力 


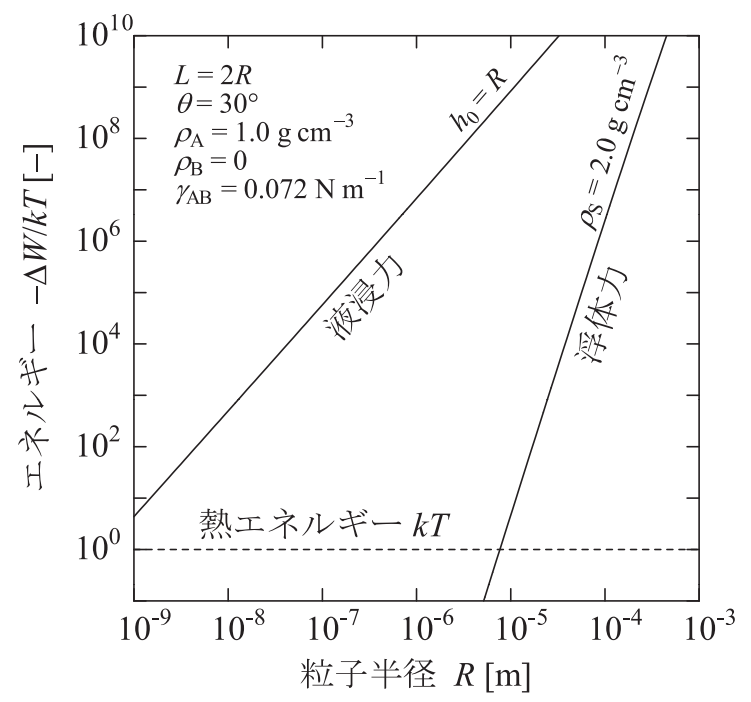

Fig. 4 浮体力と液浸力のポテンシャルエネルギーに与える 粒子半径の影響 ${ }^{10)}$ 。

の場合）を入力值として, 二種類の横毛管力のポテンシャ ルエネルギー $\Delta W$ を粒子半径 $R$ の関数として算出した ${ }^{10)}$ 。 その結果を Fig. 4 に示す。ここでは, 温度 $T=25^{\circ} \mathrm{C}$ に おける粒子の熱エネルギー $k T$ （ブラウン運動の大きさ に相当）によって， $\Delta W$ は規格化されている。

粒子半径 $R$ の減少とともに，浮体力は液浸力よりも 急激に小さくなっている。浮体力は $R<10 \mu \mathrm{m}$ では無視 小であるが，液浸力は $R=10 \mathrm{~nm}$ においてもかなり大き い。この劇的な違いは, 液表面の変形の違いに起因する。 浮いている小さな粒子は液表面を十分に変形させるには 軽すぎるため，生じる浮体力は無視小である。一方，液 浸力の場合，粒子は固体基板によって垂直方向の位置を 制限されている。そのため，粒子が小さくなっても，液 表面の変形度はあまり変化せず, その結果, 十分に強い 引力が粒子間に働く。

\section{4 流体シミュレーションの方法}

数值流体力学 (computational fluid dynamics, CFD) とは，流体の運動に関する Navier-Stokes 方程式または その派生式をコンピュータで解くことにより, 流体の圧 力，流速，密度などを観察しようとする手法である。 CFD では，空間を離散的に扱うため，物体形状および 周りの空間を離散化する必要があり，一般的には格子で 表現する。以下では，二相系と固体表面のモデル化につ いて述べる ${ }^{16)}$ 。CFDの基礎については，文献 ${ }^{17-20) を ~}$ 参照されたい。

\section{$4 \cdot 1$ 二相系のフェイズフィールドモデル ${ }^{19,20)}$}

Fig. 5 に示すように，相 $\mathrm{A}$ および相 B の二相（気液 または液液）が共存する系を考える。フェイズフィール (a)

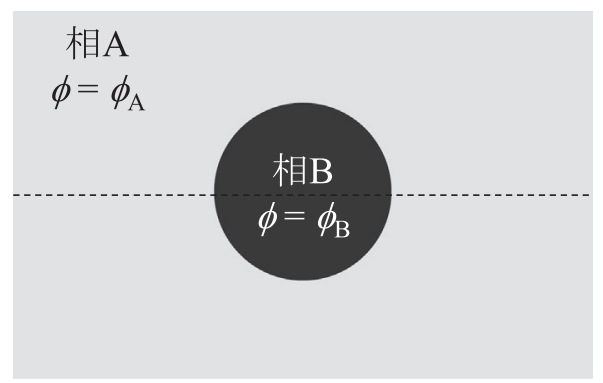

(b)

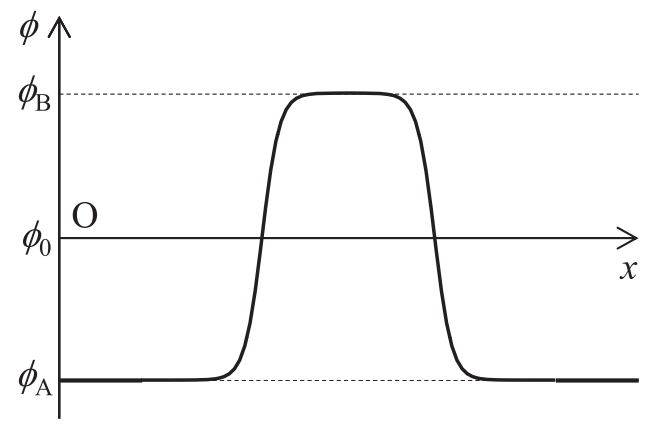

Fig. 5 (a)二相系の概念図, (b) 秩序変数分布の断面図 ${ }^{16)}$ 。

ドモデル (phase-field model) では, $\phi$ という秩序変数 (order parameter) の值によって各相を識別する。相 A および相 Bを，それぞれ $\phi=\phi_{\mathrm{A}}$ または $\phi=\phi_{\mathrm{B}}$ （ただし， $\left.\phi_{\mathrm{A}}<\phi_{\mathrm{B}}\right)$ となる領域と定義し，その中間の值 $\phi_{\mathrm{A}}<\phi<\phi_{\mathrm{B}}$ を示す領域を界面と見なす。ここで, 一成分気液共存系 では秩序変数は流体の密度に, 二成分液液共存系では秩 序変数は流体の組成分率に，それぞれ相当すると考えて よい。

界面以外のバルク相の自由エネルギー密度 $f_{0}(\phi)$ は

$$
f_{0}(\phi)=-\frac{A}{2} \phi^{2}+\frac{B}{4} \phi^{4}
$$

で与えられる。ただし， $A$ と $B$ は正の定数である。こ の $f_{0}(\phi)$ は, $\phi=\phi_{\mathrm{A}}, \phi_{\mathrm{B}}$ において極小值をもつため

$$
\begin{aligned}
& f^{\prime}(\phi)=-A \phi+B \phi^{3}=B \phi\left(\phi-\phi_{\mathrm{A}}\right)\left(\phi-\phi_{\mathrm{B}}\right) \\
& \phi_{\mathrm{A}}=-\sqrt{\frac{A}{B}}, \quad \phi_{\mathrm{B}}=\sqrt{\frac{A}{B}}
\end{aligned}
$$

から， $f_{0}(\phi)$ の概形は Fig. 6 のようになる。バルク相の 自由エネルギー密度に界面エネルギー密度を加えて体積 要素 $\mathrm{d} V\left(=\mathrm{d}^{3} \mathbf{x}=\mathrm{d} x \mathrm{~d} y \mathrm{~d} z\right)$ について積分すれば，系全体 の自由エネルギー $F$ が得られる。

$$
F[\phi(\mathbf{x}, t)]=\frac{1}{\beta} \int \mathrm{d} V\left[f_{0}(\phi)+\frac{K}{2}|\nabla \phi|^{2}\right]=\frac{1}{\beta} \int f \mathrm{~d} V
$$

ここで，Kは界面張力を決める定数 $(>0), \beta=1 / k T$ である。

\section{$4 \cdot 2$ 濡れ性をもつ固体表面のモデル化}

濡れ性のある固体表面のモデルとして最も一般的なも のは, Cahn 理論 ${ }^{21)}$ に基づく濡れポテンシャルを Eq. (14) 


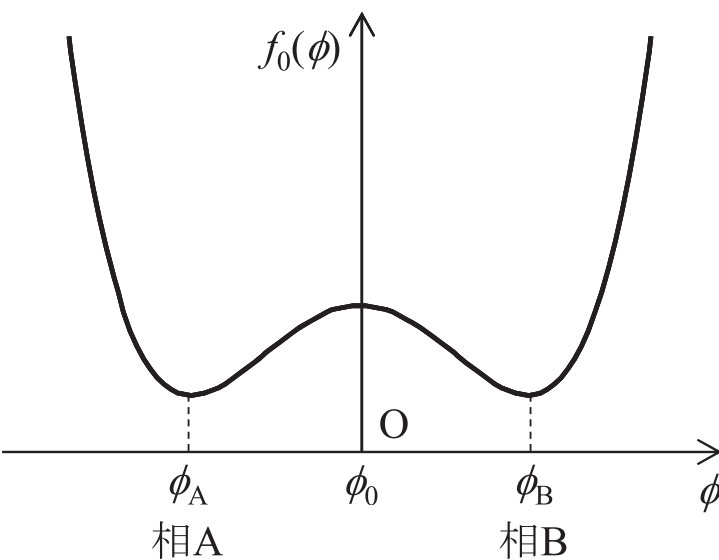

Fig. 6 バルク相の自由エネルギー密度と秩序変数の関係 ${ }^{16)}$ 。

に付加し，これを系の自由エネルギーとして用いること である。一方，筆者らの方法は，付加的なポテンシャル を用いず，二相流体の構成要素である相 A または相 B によって，固体表面を構成しようとするものである ${ }^{22)}$ 。 固体表面に扮ける秩序変数 $\phi\left(\mathbf{x}_{\mathrm{S}}, t\right)$ を $\left[\phi_{\mathrm{A}}, \phi_{\mathrm{B}}\right]$ の範 囲内のある一定值に固定しておけば，固体表面近傍の二 相流体は，Eq.（14）で与えられる系全体の自由エネル ギーを最小にするように，自律的に時間発展する。 $\phi\left(\mathbf{x}_{\mathrm{S}}\right.$, $t) \equiv \phi_{\mathrm{A}}$ の固体表面には相 $\mathrm{A}$ が, $\phi\left(\mathbf{x}_{\mathrm{S}}, t\right) \equiv \phi_{\mathrm{B}}$ の固体表面 には相 B が，それぞれ自律的に集まる。 $\phi\left(\mathbf{x}_{\mathrm{S}}, t\right) \equiv \phi_{0}$ （た だし， $\left.\phi_{0}=\left(\phi_{\mathrm{A}}+\phi_{\mathrm{B}}\right) / 2\right)$ の固体壁は，相 $\mathrm{A}$ および相 $\mathrm{B}$ に対して同じ親和性をもつため，液滴に対して接触角 $90^{\circ}$ を与える。 $\phi\left(\mathbf{x}_{\mathrm{S}}, t\right) \equiv \phi_{0}$ の固体粒子は，二相の界面に 強く吸着して界面活性を示す。

以上のように, $\phi\left(\mathbf{x}_{\mathrm{S}}, t\right)$ を $\left[\phi_{\mathrm{A}}, \phi_{\mathrm{B}}\right]$ の範囲内のある 一定值に固定するだけで，固体表面の濡れ性を自由に設 定することが可能となる。さらに，固体表面における秩
序変数として二個以上の異なる值を規則的またはランダ ムに与えたりすることにより，化学的に均質な表面ばか りでなく，化学的に不均質な表面も表現することができ る。

\section{5 流体シミュレーションの適用例}

\section{$5 \cdot 1$ 固体壁面上の液滴 ${ }^{22)}$}

Fig. 7 に示すように, 無重力下において, 円形の水滴 を三種類の親水性固体壁面上に静置した状態からシミュ レーションを行った。Fig. 7 (A) の固体表面は化学的 に均質であるが, 一方, Fig. 7 (B) と Fig. 7 (C) の固 体表面は化学的に不均質であり, その不均質性は後者の 方が強い。これらの固体表面は, 平均的に等しい親水度 をもつが, 異なる化学的不均質性を示す。

Fig. 7 から, 初期において円形であった水滴は, 固体 表面上を濡らすように変形しながら広がってゆき，その 展開はあるところで止まってしまうことがわかる。この とき, 水滴は, 気液, 気固, および固液の界面張力がちょ うど釣りあった力学的平衡状態にある。この状態にある 水滴の前進接触角 (advancing contact angle, $\theta_{\mathrm{A}}$ ) は, Fig. 7 (A) - (C) の場合, それぞれ $\theta_{\mathrm{A}}=68.4^{\circ}, 68.4^{\circ}$, $80.4^{\circ}$ である。この $\theta_{\mathrm{A}}$ の違いは，気液固の三相が接する 接触点 (三次元の場合は接触線) が, 固体表面上に存在 する化学的に不均質なサイトによって, 動けないように ピン止め (pinning) されたために生じる。このピン止 め効果は化学的不均質性が強い固体表面ほど強くなるた め，たとえ平均的な親水度が同じ固体表面であっても， 不均質性の強い固体表面は, 均質表面に比べて大きい前 進接触角を与える。

逆に, 液滴が後退する方向に動いた後, 力学的平衡状 態に達する場合も考えられる。このときの接触角は，後
(A)

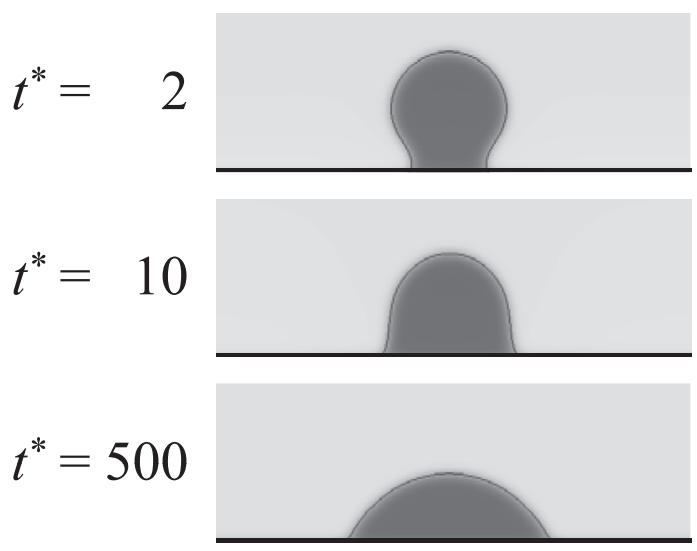

Fig. 7 化学的不均質性の異なる親水性固体壁面上における液滴の挙動： 均質性の大きい表面 ${ }^{22)}$ 。
(B)

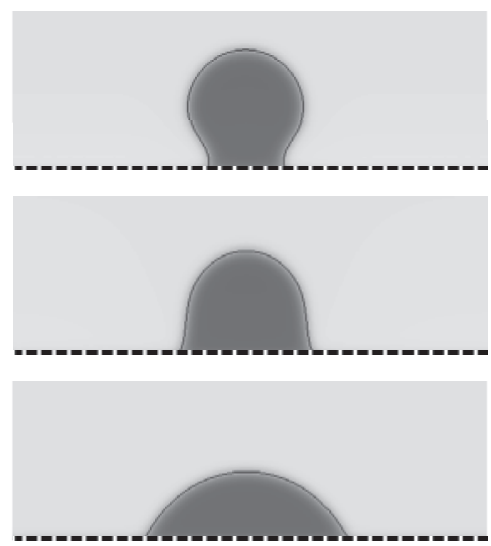

（A）均質な表面 , (B)
(C)

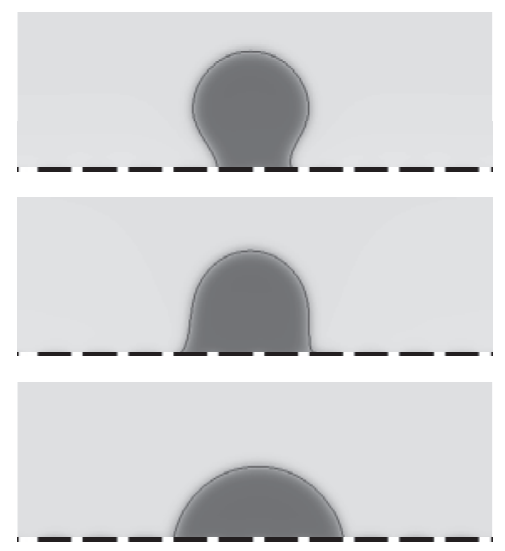

B）不均質性の小さい表面, (C) 不 
退接触角 (receding contact angle, $\theta_{\mathrm{R}}$ ) と呼ばれる。こ の $\theta_{\mathrm{R}}$ は, 固体表面の化学的不均質性が強くなるほど, 小さくなる。すなわち, 化学的に不均質な固体表面では, $\theta_{\mathrm{A}}>\theta_{\mathrm{R}}$ となるためヒステリシスを生じ, 不均質性が強 くなるほど接触角の差 $\theta_{\mathrm{A}}-\theta_{\mathrm{R}}(>0)$ は大きくなる。完 全に均質な固体表面では， $\theta_{\mathrm{A}}=\theta_{\mathrm{R}}$ となる。

化学的不均質の他に, 物理的不均質性である凹凸の影 響もシミュレーションによって調べることは可能であ る。

\section{$5 \cdot 2$ 毛管架橋力 ${ }^{23}$}

厚さ $5 \Delta x$ の液膜で覆われた二個の円柱状粒子（表面 は親水性，半径 $R=64.0 \Delta x ）$ が，平行に配置されている 場合を考える。ここで， $\Delta x$ は CFD シミュレーションの 格子幅を表わし，重力の影響は無視されている。

粒子間に働く単位長さ当たりの相互作用力 $F$ を，Fig 8 に示す。ここで, $\gamma_{\mathrm{LV}}$ は気液の界面張力を表す。表面 間距離 $D \geq 15 \Delta x$ のとき，粒子どうしに働く力はほぼゼ ロである。それらが互いに近づくとき，相互作用力は $D$ $=14 \Delta x$ において突然引力的になる。Fig. 8 の挿入眓に より，引力が発生する以前は，粒子表面に吸着した液膜 は互いに独立に存在しているが，引力の発生と同時に， それらが合一して粒子どうしを架橋している様子が見ら れる。すなわち，粒子間の間隙に形成された液架橋が， 粒子間に引力（毛管架橋力）を発生させるのである。

\section{$5 \cdot 3$ 横毛管力 ${ }^{23,24}$}

重力下において，水面上に二個の円柱状粒子（半径 $R$ $=7.9 \Delta x)$ が水平に固定された場合を考える。Fig. 9 (A) 一（C）に示すように，粒子近傍の水面は，粒子表面の 濡れ性に応じて, 変形していることがわかる。すなわち， 親水性表面の粒子は水面を引き上げ，一方，疎水性表面 の粒子は水面を押し下げている。

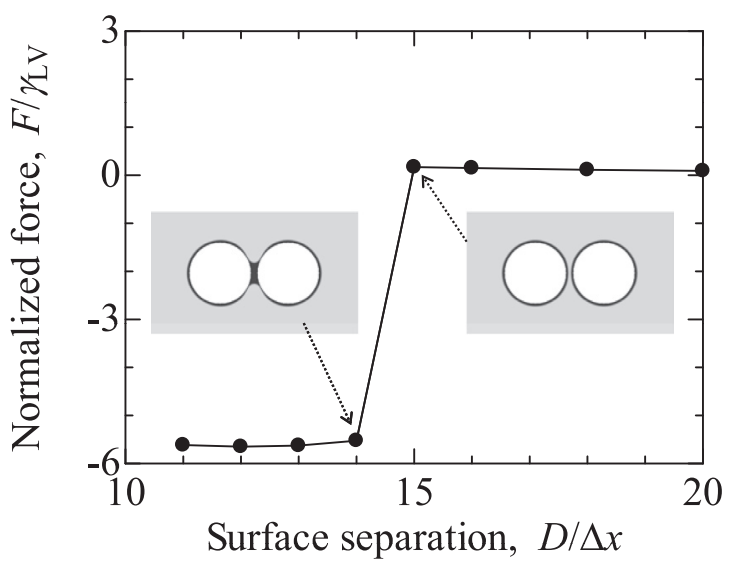

Fig. 8 蒸気中で液体薄膜に覆われた二つの円柱の間に働く 相互作用力（挿入図は $D=14 \Delta x, 15 \Delta x$ でのスナップ ショット $)^{23)}$ 。
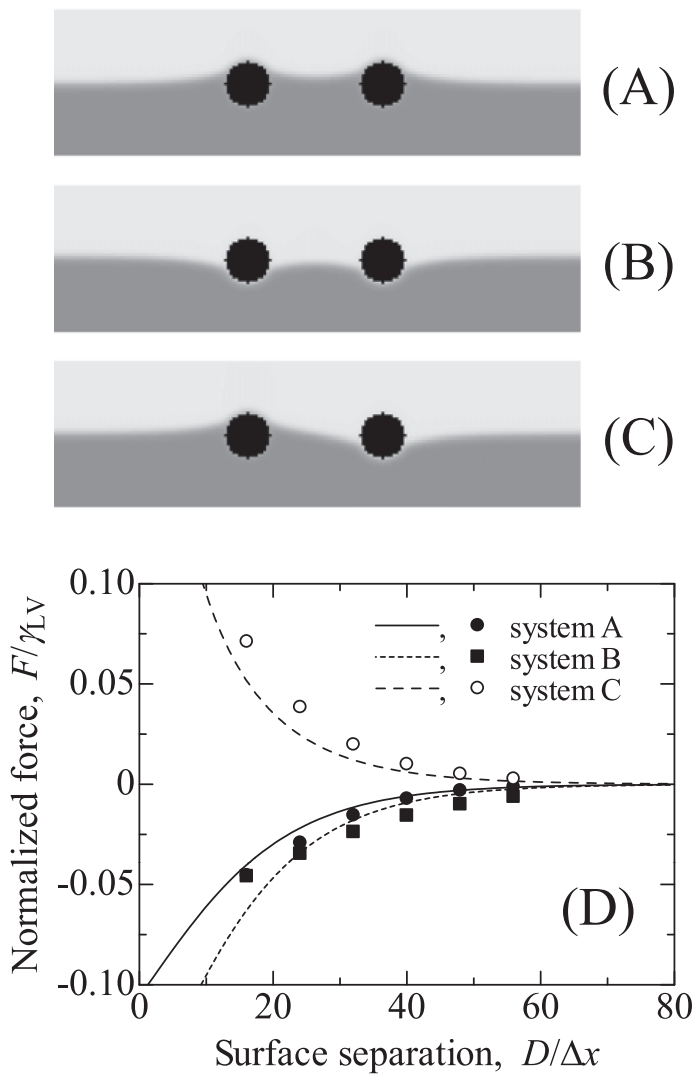

Fig. 9 気液界面に置かれた二つの円柱。 $D=32.2 \Delta x$ でのス ナップショット：(A) 二つの親水性円柱, (B) 二つ の疎水性円柱，（C）親水性円柱と疎水性円柱。（D） 相互作用力 ${ }^{23)}$ 。

粒子どうしに働く単位長さ当たりの相互作用力 $F$ を, Fig. 9 (D) に示す。二個の粒子の表面がいずれも親水 性（Fig.9(A)）かいずれも疎水性（Fig.9（B））の場合, 引力が働く。一方, 親水性粒子と疎水性粒子 (Fig. 9 (C)) の間には斥力が働く。この横毛管力は, いずれの粒子ペ アについても, 表面間距離が小さくなるほど強くなって いる。この毛管架橋力の距離依存性について, CFD シ ミュレーションの結果は理論的予測とよく一致してい る。

\section{$5 \cdot 4$ Pickering エマルション ${ }^{25)}$}

Fig. 10 のように, 単一の円形油滴とその表面に 20 個 の界面活性粒子をそれぞれ静置し，その周囲を水相で満 たした系を考える。上下には一定速度で互いに反対方向 へ移動する壁面を設定し, 水平方向には周期境界条件を 課した。この Pickering エマルションの変形度は, 時間 とともに大きくなっている。

Fig. 11 のように，二個の円形油滴とその表面に 6 個 の界面活性粒子をそれぞれ静置し, その周囲を水相で満 たした系を考える。相手側の油滴に最接近している界面 活性粒子がその油滴表面に接触することにより, 油滴ど 

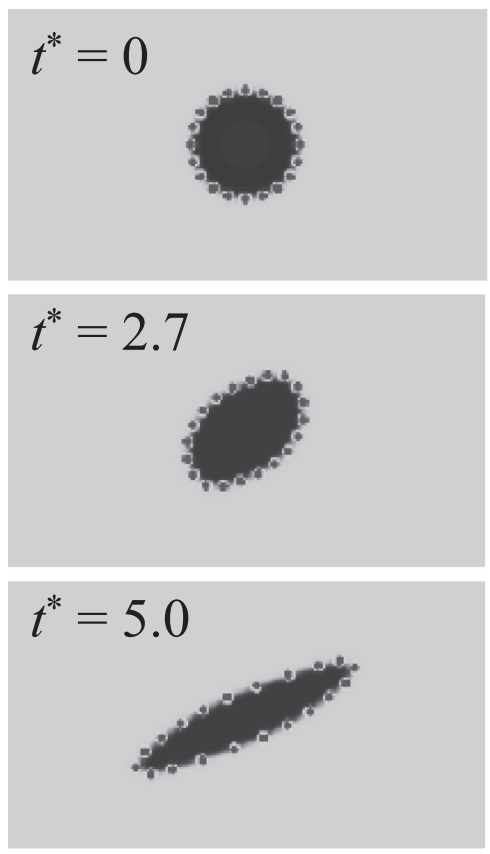

Fig. 10 界面活性粒子が付着した油滴のせん断流による変形 ${ }^{25)}$ 。
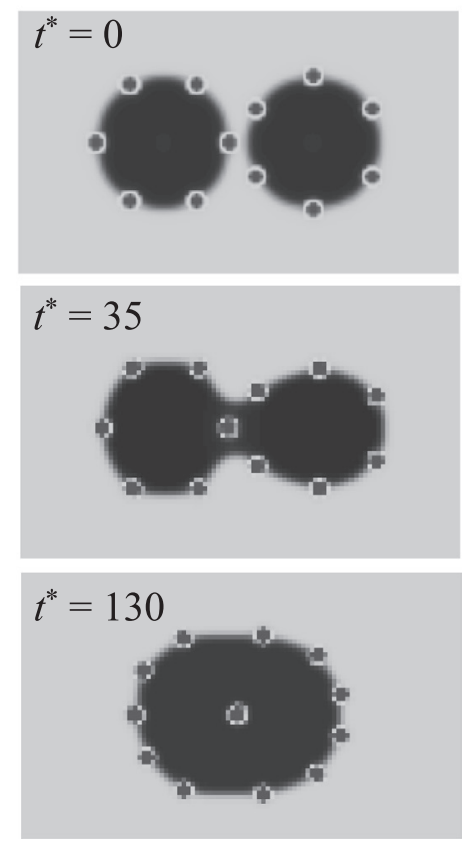

Fig. 11 界面活性粒子が付着した油滴どうしの合一 ${ }^{25)}$ 。

うしの合一がはじまり，最終的にはほぼ円形の一つの油 滴になる。

\section{6 おわりに}

本稿では，固体表面上の濡れ，二相流体中や二相界面 における粒子間力, 粒子集団の挙動や流れ場の影響につ いて, 流体シミュレーションによる著者らの解析結果の 一部を紹介した。今後, 本手法を含めた計算機シミュレー
ションが，「二相流体と固体壁面・粒子とが共存する系」 に対して，ますます広く適用されてゆくと考えられる。 このような「界面」と「流動場」が重要となる系の「非 平衡現象」の理解が進めば, 複合材料, 複合粒子, 化粧 品, 食品, 医薬品などの製造プロセスを高精度化・高効 率化するために，重要な指針を与えるであろう。

\section{謝 辞}

本研究の一部は, ホソカワ粉体工学振興財団, 文部科 学省 科学研究費補助金, JSPS-CTC (No.18004)「先進 微粒子ハンドリング科学」の支援を受けて行われた。こ こに記して謝意を表する。

\section{文 献}

1）物質・材料研究機構 粒子アセンブル研究会 編, 粒子 集積化技術の世界，工業調査会（2001）。

2) D. F. Evans \& H. Wennerström, The Colloidal Domain $2^{\text {nd }}$ ed., pp.264-9, Wiley-VCH (1999).

3) J. N. Israelachvili, Intermolecular and Surface Forces $2^{\text {nd }}$ ed., pp.330-4, Academic Press (1991)；日本語訳, 分子間力と表面力 第二版, pp.318-22, 朝倉書店 (1996).

4) 奥山喜久夫, 増田弘昭, 諸岡成治, 微粒子工学, pp.32-41，オーム社 (1992).

5) P. Petrov, S. Miklavic, U. Olsson et al., Langmuir, 11, 3928-36 (1995).

6) D. A. Antelmi, P. Kékicheff, \& P. Richetti, Langmuir, 15, 7774-88 (1999).

7) H. Wennerström, K. Thuresson, P. Linse et al., Langmuir, 14, 5664-6 (1998).

8) K. Kočevar, A. Borštnik, I. Muševič et al., Phys. Rev. Lett., 86, 5914-7 (2001).

9) H. Shinto, K. Kobayashi, T. Hyodo et al., Chem. Lett., 34, 1318-9 (2005)

10）新戸浩幸, インクジェット技術における微小液滴の吐 出・衝突・乾燥（技術情報協会 編）, pp.85-102（2009）

11）永山國昭, 自己集積の自然と科学, pp.45-68, 丸善(1997).

12) P. A. Kralchevsky \& K. Nagayama, Adv. Colloid Interface Sci., 85, 145-92 (2000).

13) P. A. Kralchevsky \& N. D. Denkov, Curr. Opin. Colloid Interface Sci., 6, 383-401 (2001).

14) P. A. Kralchevsky \& K. Nagayama, Particles at Fluid Interfaces and Membranes, pp.287-395, pp.503-16, Elsevier (2001).

15) P. A. Kralchevsky, K. D. Danov, \& N. D. Denkov, Handbook of Surface and Colloid Chemistry $3^{\text {rd }}$ ed., (K. S. Birdi ed.), pp.197-377, CRC Press (2008).

16）新戸浩幸, 粉体工学会誌, 46, 25-34（2009）.

17）梶島岳夫, 乱流の数值シミュレーション,養賢堂 (1999).

18）平野博之, 流れの数值計算と可視化第二版, 丸善 (2004).

19) A. Prosperetti \& G. Tryggvason ed., Computational Methods for Multiphase Flow, Cambridge University Press (2007). 
20）稲室隆二, 物性研究, 77, 197-232 (2001).

21) J. W. Cahn, J. Chem. Phys., 66, 3667-72 (1977).

22) D. Iwahara, H. Shinto, M. Miyahara et al., Langmuir, 19, 9086-93 (2003)

23) H. Shinto, D. Komiyama \& K. Higashitani, Adv. Pow- der Technol., 18, 643-62 (2007).

24) H. Shinto, D. Komiyama \& K. Higashitani, Langmuir, 22, 2058-64 (2006).

25）新戸浩幸，小宮山大介，寺本直史ら，粉体工学会 2007 年度春期研究発表会, 東京, 講演論文集, pp.67-8（2007）. 